\title{
THE LLANDOVERY-WENLOCK BOUNDARY IN THE RUSSIAN ARCTIC
}

\author{
Peep MÄNNIK ${ }^{\mathrm{a}}$, Anna I. ANTOSHKINA ${ }^{\mathrm{b}}$, and Tatyana M. BEZNOSOVA ${ }^{\mathrm{b}}$
}

a Institute of Geology, Tallinn Technical University, Estonia pst. 7, 10143 Tallinn, Estonia; mannik@gi.ee

b Institute of Geology, Komi Science Centre, Uralian Division of the Russian Academy of Sciences, Pervomajskaya 54, 167982 Syktyvkar, Komi Republic, Russia; Antoshkina@geo.komisc.ru

Received 21 January 2000, in revised form 7 February 2000

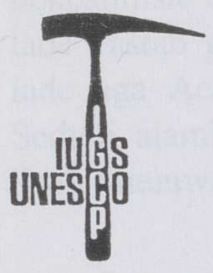

IGCP Project 406

Circum-Arctic Lower-

Middle Palaeozoic

Vertebrate Palaeontology

and Biostratigraphy

\begin{abstract}
The position of the Llandovery-Wenlock boundary in the Timan-northern Ural region and Severnaya Zemlya has been under discussion for a long time. Datings based on different groups of fauna seem to be inconsistent; conodonts indicate that in both regions this boundary lies considerably higher in the sequence than considered until now. The conodont datings agree well with correlations based on sea level fluctuations.
\end{abstract}

Key words: stratigraphy, Llandovery-Wenlock boundary, Silurian, Timan-northern Ural region, Severnaya Zemlya, Russia.

\section{INTRODUCTION}

Lithologically, the Silurian sequences in the Timan-northern Ural region and on Severnaya Zemlya are similar, being represented by various, as a rule highly fossiliferous shallow-water (tidal flat, lagoonal, shoal, shallow shelf) facies (Kurik et al. 1982; Markovskij \& Smirnova 1982; Antoshkina \& Beznosova 1987; Antoshkina 2000; Melnikov \& Zhemchugova 2000; Männik et al. in press). The position of the Llandovery-Wenlock (Telychian-Sheinwoodian) boundary in both regions has been problematic for a long time (Antoshkina \& Beznosova 1999; Männik \& Martma 1999; Männik in press; Männik et al. in press). Traditionally, in the Timan-northern Ural region this boundary was considered to correspond to the boundary between the Filipp"el' and Sed"el' stages, and on Severnaya Zemlya to the boundary between the Golomyannyj and Srednij 
formations. However, the distribution of conodonts does not agree with these datings. The alternatives for the Llandovery-Wenlock boundary in these regions will be discussed below.

\section{IDENTIFICATION OF THE LLANDOVERY-WENLOCK BOUNDARY}

The Llandovery-Wenlock boundary was defined by Bassett et al. (1975) in its type section at Hughly Brook near Leasows Farm, Welsh Borderland, and was later ratified by the Subcommission on Silurian Stratigraphy of the IUGS (Holland 1980). It coincides with the boundary between the Purple Shale and Buildwas formations and is recognized in the sequence by a transition from predominantly purple to grey mudstones (Bassett et al. 1975). Although no graptolites were recorded from the type section, it has been assumed that the base of the Cyrtograptus centrifugus graptolite Biozone coincides with the base of the Wenlock Series (Holland 1980). Mabillard \& Aldridge (1985) give a detailed description of the microfaunal and microfloral biostratigraphy across the Llandovery-Wenlock boundary at Leasows. They conclude that the base of the Wenlock Series in the type section does not coincide with the base of any microfossil or macrofossil biozone, and that it lies somewhere in the uppermost part of the range of the conodont Pterospathodus amorphognathoides Walliser.

P. amorphognathoides, together with most taxa (at least $80 \%$ ) of the rich Telychian conodont fauna, became extinct during the Ireviken Event, which caused drastic changes in the latest Telychian-earliest Sheinwoodian marine faunas (Aldridge et al. 1993; Jeppsson \& Männik 1993; Kaljo et al. 1996; Jeppsson 1997a, 1998). Detailed study of the conodont faunal changes during this event has revealed at least eight levels (datums) of disappearances. Comparison of conodont successions from Gotland and Leasows has led to the conclusion that the Llandovery-Wenlock boundary, as it is defined in its type section, coincides, or lies very close to, Datum 2 of the Ireviken Event (Aldridge et al. 1993; Jeppsson 1997b and pers. comm.). At this datum, the severest changes took place in the conodont faunas. Together with several other taxa Apsidognathus and Aulacognathus, whose apparatuses contained morphologically very distinct platform elements, disappeared. As this level is particularly easy to recognize in the carbonate facies, it allows us to define the Llandovery-Wenlock boundary in sections where graptolites are rare or missing.

\section{THE BOUNDARY IN THE TIMAN-NORTHERN URAL REGION}

Considering mainly the distribution of brachiopods, stromatoporoids, and corals, the Llandovery-Wenlock boundary in the Timan-northern Ural region has been correlated with the boundary between the Filipp"el' and Sed"el' stages (Brejvel' et al. 1980; Nestor 1987; = the boundary between the Filipp"el' and 
Marshrutnyj stages in the Subpolar Urals after Antsygin et al. 1993; Fig. 1). However, the results of extensive conodont studies do not agree with the officially accepted stratigraphy. The obvious inadequacy of datings, partly caused by the previous misinterpretation of conodont data, is also evidenced by problems appearing during sedimentological correlations.

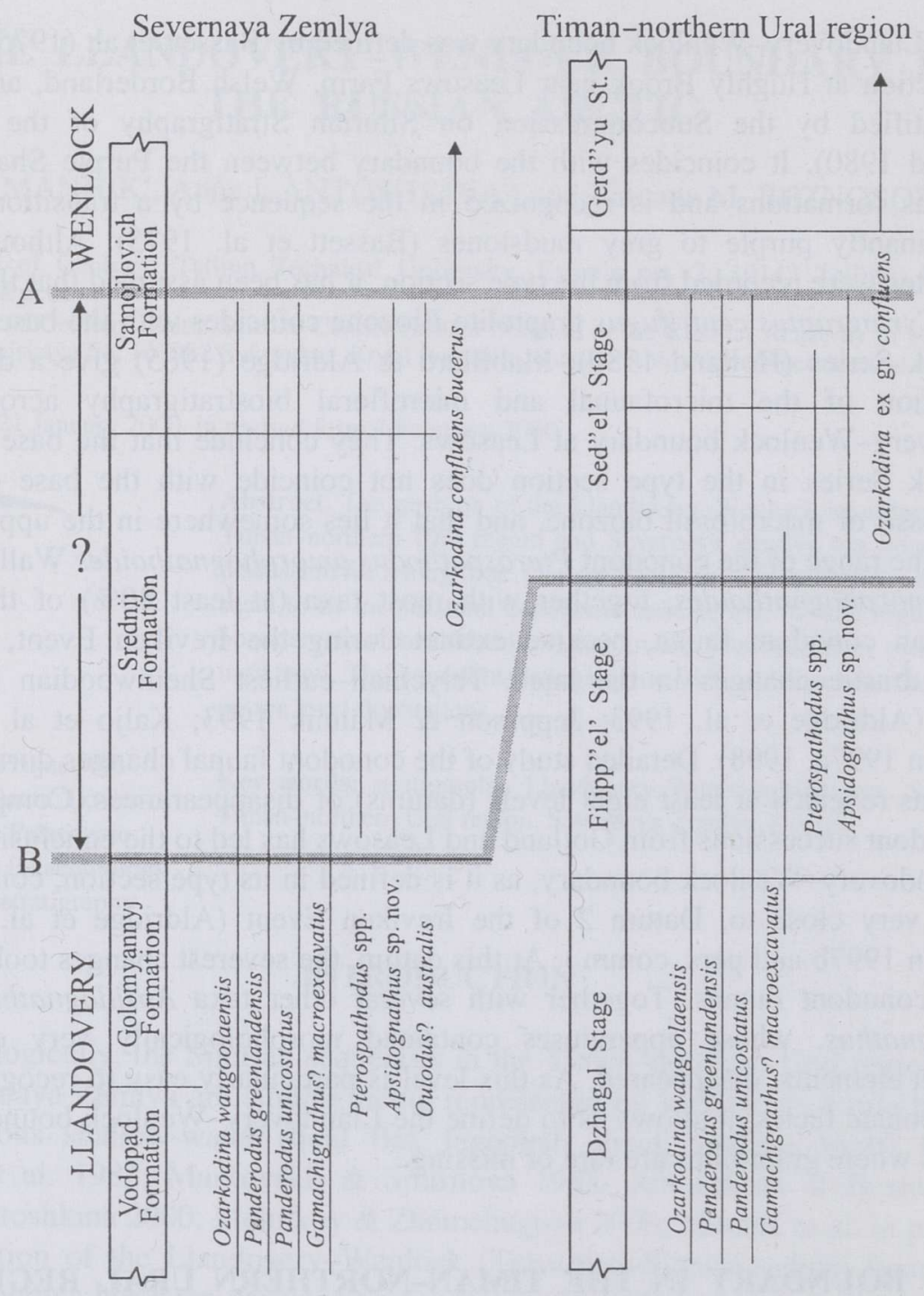

Fig. 1. Distribution of selected conodont taxa in the Llandovery-Wenlock strata on Severnaya Zemlya and in the Timan-northern Ural region. A, position of the Llandovery-Wenlock boundary based on the distribution of conodonts (= the level of disappearance of Apsidognathus); B, position of the Llandovery-Wenlock boundary used in official stratigraphical schemes (e.g. Nestor 1987; Antsygin et al. 1993). 
All over the world, Telychian sediments are known to be formed under the conditions of a global transgression, followed by a sea level fall in the earliest Sheinwoodian (Johnson et al. 1991). However, in the Timan-northern Ural region the sequence of changes in sea level seems to be different. The Filipp"el' Stage, traditionally correlated with the Telychian (Nestor 1987; Antsygin et al. 1993), is characterized by extremely shallow-water sediments which formed during a major sea level fall (Antoshkina 2000; Melnikov \& Zhemchugova 2000). The Filipp"el' regression was followed by an abrupt sea level rise at the beginning of Sed"el' (Marshrutnyj) time (Antoshkina 2000, fig. 3), traditionally considered to correspond already to the Wenlock (Nestor 1987; Antsygin et al. 1993).

However, the correlation of the Filipp"el' Stage with the Telychian based on the occurrence of an association of icriodellids (Melnikov \& Zhemchugova 2000) is not convincing. Icriodella is a long-ranging genus, and in the region under discussion it is represented by species unknown from the other parts of the world (Männik pers. observations). Moreover, a typical Telychian conodont fauna appears higher in the sequence, in the lowermost strata of the Sed"el' Stage (Melnikov \& Zhemchugova 1999, figure; 2000, fig. 4). The specimen(s) of Apsidognathus from the Filipp"el' Stage, referred to in Melnikov \& Zhemchugova (2000), come(s) from the uppermost part of the strata correlated with this stage in the western part of the Timan-northern Ural region (Melnikov pers. comm.).

At the beginning of Sed"el' time, the transgression caused significant changes in the marine biotas. Brachiopod faunas, characteristic of Boucot's (1979) benthic assemblages 3-5, became widespread in the Timan-northern Ural region. These assemblages of brachiopods are evidently the deepest-water ones recognized in the Silurian sequence of this region (Beznosova 2000). The appearance of the Apsidognathus-fauna in the Timan-northern Ural region in the lowermost Sed"el' Stage and its occurrence also in the upper part of this stage indicate a Telychian age for these strata (Figs. 1, 2). The Ireviken Event interval in the Timannorthern Ural region can be recognized in the upper part of the Sed"el' Stage (Melnikov \& Zhemchugova 2000, figs. 4, 5; in the upper part of the Ust'Durnayu Stage according to Antsygin et al. 1993; Fig. 2). It is characterized by the disappearance of Apsidognathus sp. nov. (=Apsidognathus tuberculatus in Melnikov \& Zhemchugova 2000 and Apsidognathus aff. A. tuberculatus in Abushik 2000; Datum 2 of the Ireviken Event), Ozarkodina waugoolaensis Bischoff, Pterospathodus spp., and Panderodus greenlandensis Armstrong. In the Timan-northern Ural region, the Telychian conodont fauna is overlain by an association of conodonts dominated by endemics and lacking any taxa allowing precise datings of the strata (Melnikov \& Zhemchugova 2000; Melnikov pers. comm.; Männik pers. observations).

Supposing that the correlations proposed above are correct (i.e. the Filipp"el' Stage $=$ Aeronian; the lower and middle parts of the Sed"el' Stage $=$ Telychian), the eustatic curves of the Timan-northern Ural region illustrated by Antoshkina (2000, fig. 3) and by Melnikov \& Zhemchugova (2000, fig. 6) will fit perfectly with the standard curve by Johnson et al. 1991. 


\begin{tabular}{|c|c|c|c|c|c|}
\hline \multirow{2}{*}{ 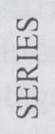 } & \multirow[t]{2}{*}{ STAGE } & \multicolumn{3}{|c|}{$\begin{array}{l}\text { SUBPOLAR URALS } \\
\text { (Nestor 1987) } \\
\text { (Antsygin ct al. 1993) }\end{array}$} & \multirow{2}{*}{$\begin{array}{c}\text { SEV. ZEM. } \\
\text { (Männik 1997) } \\
\text { FORMATION }\end{array}$} \\
\hline & & STAGE & STAGE & FORMATION & \\
\hline 3 & Sheinwoodian & Gerd"yu & Padimejtyvis & Padimejtyvis & \multirow{2}{*}{ Samojlovich } \\
\hline \multirow{5}{*}{ 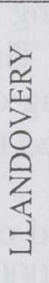 } & \multirow{2}{*}{ Telychian } & \multirow{2}{*}{ Sed" ${ }^{\prime \prime} l^{\prime}$} & Ust'Durnayu & Ust'Durnayu & \\
\hline & & & Marshrutnyj & Marshrutnyj & Srednij \\
\hline & \multirow{2}{*}{ Aeronian } & Filipp" ${ }^{\prime \prime} l^{\prime}$ & Filipp"'el' & Filipp ${ }^{\prime \prime} \mathrm{el}^{\prime}$ & Golomyannyj \\
\hline & & \multirow{2}{*}{ Dzhagal } & Lolashor & Lolashor & \multirow{2}{*}{ Vodopad } \\
\hline & Rhuddanian & & Yarenej & Yarenej & \\
\hline
\end{tabular}

Fig. 2. Correlation of regional stratigraphical units in the Subpolar Urals and Severnaya Zemlya with standard Silurian stages and series based on conodonts. Dotted lines indicate problematic correlations between Severnaya Zemlya and the Subpolar Urals. Gaps are not shown in this scheme. Sev. Zem., Severnaya Zemlya; W., Wenlock.

\section{THE BOUNDARY ON SEVERNAYA ZEMLYA}

For a long time, based on the distribution of stromatoporoids, tabulate corals, ostracodes, and brachiopods, the Golomyannyj Formation has been considered of Telychian age, the Srednij Formation of early Wenlock age, the lower part of the Samojlovich Formation of late Wenlock age, and the upper part of this formation of Ludlow age (Kurik et al. 1982). The Llandovery-Wenlock boundary on Severnaya Zemlya has been treated as coinciding with the boundary between the Golomyannyj and Srednij formations. According to the above correlations, also on Severnaya Zemlya the Telychian is represented by strata corresponding to a major marine regression, followed by an extensive transgression in early Wenlock time (Männik et al. in press).

However, the occurrence of the Apsidognathus-fauna in the Srednij Formation and in the lower Samojlovich Formation suggests a Telychian age for these strata (Figs. 1, 2). The conodonts Ozarkodina confluens bucerus Viira and Kockelella cf. ortus (Walliser), and the vertebrate Loganellia grossi Fredholm indicate a middle to late Wenlock age (but not Ludlow) for the upper part of the Samojlovich Formation (Männik 1997 and in press; Märss pers. comm.).

The Ireviken Event interval on Severnaya Zemlya can be recognized in the middle part of the Samojlovich Formation. It is characterized by the disappearance of Apsidognathus sp. nov. (Datum 2 of the Ireviken Event), Ozarkodina waugoolaensis Bischoff, Oulodus? australis Bischoff, Pterospathodus spp., Panderodus unicostatus (Branson \& Mehl), and Panderodus greenlandensis Armstrong (Fig. 1). As the Telychian conodont fauna is overlain by a middle-late Wenlock association of conodonts, it is evident that the lower 
Wenlock, but probably also the uppermost Llandovery, correspond to a gap in the Severnaya Zemlya section (Männik \& Martma 1999; Männik in press).

\section{CONCLUSIONS}

The datings based on different groups of fossils seem to be inconsistent, and therefore further studies are needed to verify the position of the LlandoveryWenlock boundary in the Timan-northern Ural and Severnaya Zemlya regions. Preferably, some other (non-biostratigraphical) methods to test the datings by faunas should be applied. Valuable information about the interval under discussion (the Llandovery-Wenlock boundary) could be obtained through the study of $\delta^{13} \mathrm{C}$ isotopes. The early Sheinwoodian $\delta^{13} \mathrm{C}$ positive excursion, corresponding to the Ireviken Event, and to the strata just above it, has been recognized all over the world (e.g. Andrew et al. 1994; Wentzel \& Joachimski 1996; Kaljo et al. 1998; Märss et al. 1998).

\section{ACKNOWLEDGEMENTS}

The authors are indebted to L. Jeppsson, Lund University, Sweden, and S. Melnikov, Timan-Pechora Scientific and Research Centre, Ukhta, Russia, for kind permission to study their collections of conodonts and for very productive discussions. The manuscript was much improved following the comments of the reviewers D. Kaljo and H. Nestor. This study was supported by grant No. 3749 from the Estonian Science Foundation.

\section{REFERENCES}

Aldridge, R. J., Jeppsson, L. \& Dorning, K. J. 1993. Early Silurian episodes and events. J. Geol. Soc. London, 150, 501-513.

Andrew, A. S., Hamilton, P. J., Mawson, R., Talent, J. \& Whitford, D. J. 1994. Isotopic correlation tools in the mid-Palaeozoic and their relation to extinction events. J. Austral. Petrol. Explorers Ass., 34, 268-277.

Antoshkina, A. I. 2000. The Silurian of the Timan-northern Ural region. Proc. Estonian Acad. Sci. Geol., 49, 69-84.

Antoshkina, A. I. \& Beznosova, T. M. 1987. About connections between the evolutionary stages of the upper Ashgill to Silurian biota and sedimentary cycles. In Stratigrafiya $i$ paleoekologiya paleozoya $i$ kajnozoya Severo-Vostoka evropejskoj chasti SSSR (Tsyganko, V. S., Chermnykh, N. A. \& Borintseva, N. A., eds.). Tr. In-ta geol. Komi filiala AN SSSR, 62, 4-16 (in Russian).

Antoshkina, A. I. \& Beznosova, T. M. 1999. The Llandovery-Wenlock boundary in the Urals. In Geologiya $i$ mineral'nye resursy evropejskogo severo-vostoka Rossii: novye rezul'taty $i$ novye perspektivy. Materialy XIII Geologicheskogo s"ezda Respubliki Komi, Vol. II (Yushkin, N. P., ed.), pp. 187-189. Inst. geol. Komi nauch. tsentra UrO RAN, Syktyvkar (in Russian). 
Antsygin, N. Ya., Popov, B. A. \& Chuvashov, B. I. (eds.). 1993. Stratigraficheskie skhemy Urala. IGiG UNTs RAN, Ekaterinburg (in Russian).

Bassett, M. G., Cocks, L. R. M., Holland, C. H., Rickards, R. B. \& Warren, P. T. 1975. The type Wenlock Series. Rep. Inst. Geol. Sci. London, 75/13.

Beznosova, T. M. 2000. Silurian brachiopods in the Timan-northern Ural region: zonation and palaeoecology. Proc. Estonian Acad. Sci. Geol., 49, 126-146.

Boucot, A. J. 1979. Évolyutsiya i tempy vymiraniya. Mir, Moscow (in Russian).

Brejvel', M. G., Papulov, G. N. \& Khodalevich, A. N. (eds.). 1980. Unifitsirovannye $i$ korrelyatsionnye skhemy Urala. Materialy i resheniya III Ural'skogo mezhvedomstvennogo stratigraficheskogo soveshchaniya. IGiG UNTs AN SSSR, Sverdlovsk (in Russian).

Holland, C. H. 1980. Silurian series and stages: decisions concerning chronostratigraphy. Lethaia, 13.

Jeppsson, L. 1997a. The anatomy of the mid-Early Silurian Ireviken Event. In Paleontological Event Horizons - Ecological and Evolutionary Implications (Brett, C. E. \& Baird, G., eds.), pp. 451-492. Columbia Univ. Pr.

Jeppsson, L. 1997b. A new latest Telychian, Sheinwoodian and Early Homerian (Early Silurian) Standard Conodont Zonation. Trans. Roy. Soc. Edinburgh: Earth Sci., 88, 91-114.

Jeppsson, L. 1998. Silurian oceanic events: summary of general characteristics. In Silurian Cycles: Linkages of Dynamic Stratigraphy with Atmospheric, Oceanic, and Tectonic Changes. James Hall Centennial Volume (Landing, E. \& Johnson, M. E., eds.). New York State Mus. Bull., 491, 239-257.

Jeppsson, L. \& Männik, P. 1993. High-resolution correlations between Gotland and Estonia near the base of the Wenlock. Terra Nova, 5, 348-358.

Johnson, M. E., Kaljo, D. \& Rong, J.-Y. 1991. Silurian eustasy. In The Murchison Symposium: Proceedings of an International Conference on the Silurian System (Bassett, M. G., Lane, P. D. \& Edwards, D., eds). Spec. Pap. Palaeont., 44, 145-163.

Kaljo, D., Boucot, A. J., Corfield, R. M., Le Herisse, A., Koren, T. N., Křiz, J., Männik, P., Märss, T., Nestor, V., Shaver, R. H., Siveter, D. J. \& Viira, V. 1996. Silurian bio-events. In Global Events and Event Stratigraphy in the Phanerozoic (Walliser, O. H., ed.), pp. 173-224. Springer-Verlag, Berlin.

Kaljo, D., Kiipli, T. \& Martma, T. 1998. Correlation of carbon isotope events and environmental cyclicity in the East Baltic Silurian. In Silurian Cycles: Linkages of Dynamic Stratigraphy with Atmospheric, Oceanic, and Tectonic Changes. James Hall Centennial Volume (Landing, E. \& Johnson, M. E., eds.). New York State Mus. Bull., 491, 297-312.

Kurik, E. Yu., Kuršs, V. M., Markovskij, V. A., Matukhin, R. G., Menner, V. Vl., Modzalevskaya, T. L., Patrunov, D. K., Samojlovich, Yu. G., Smirnova, M. A., Talimaa, V. N., Khapilin, A. F., Cherkesova, S. V. \& Abushik, A. F. 1982. On the Silurian and Devonian stratigraphy of Severnaya Zemlya. In Stratigrafiya $i$ paleontologiya devona $i$ karbona (Yuferev, O. V., ed.), pp. 65-73. Moscow (in Russian).

Mabillard, J. E. \& Aldridge, R. J. 1985. Microfossil distribution across the base of the Wenlock Series in the type area. Palaeontology, 28, 89-100.

Männik, P. 1997. Silurian conodonts from Severnaya Zemlya. In Palaeozoic Strata and Fossils of the Eurasian Arctic (Ivanov, A., Wilson, M. V. H. \& Zhuravlev, A., eds.). Ichthyolith Issues Spec. Publ., 3, 25-26.

Männik, P. Conodonts in the Silurian of Severnaya Zemlya, with special reference to the genus Ozarkodina. Geodiversitas (in press).

Männik, P. \& Martma, T. 1999. Ireviken Event and the Llandovery-Wenlock boundary on Severnaya Zemlya. In Lower-Middle Palaeozoic Events Across the Circum-Arctic (Lukševičs, E., Stinkulis, G. \& Wilson, M. V. H., eds.). Ichthyolith Issues Spec. Publ., 5, 28-29.

Männik, P., Menner, V. V., Matukhin, R. G. \& Kuršs, V. Silurian and Devonian strata on the Severnaya Zemlya and Sedov archipelagos, Russia. Geodiversitas (in press). 
Markovskij, V. A. \& Smirnova, M. A. 1982. Silurian sediments of Severnaya Zemlya Archipelago. In Geologiya arkhipelaga Severnaya Zemlya (Kaban'kov, V. Ya. \& Lazarenko, N. P., eds.), pp. 39-60. PGO “Sevmorgeologiya”, Leningrad (in Russian).

Märss, T., Caldwell, M., Gagnier, P.-Y., Goujet, D., Männik, P., Martma, T. \& Wilson, M. V. H. 1998. Distribution of Silurian and Lower Devonian vertebrate microremains and conodonts in the Baillie-Hamilton and Cornwallis Island sections, Canadian Arctic. Proc. Estonian Acad. Sci. Geol., 47, 51-76.

Melnikov, S. V. \& Zhemchugova, V. A. 1999. Reflection of early Silurian oceanic episodes and events in shallow shelf sequences of the north-eastern East European Platform. In LowerMiddle Palaeozoic Events Across the Circum-Arctic (Lukševičs, E., Stinkulis, Ģ. \& Wilson, M. V. H., eds.). Ichthyolith Issues Spec. Publ., 5, 30-33.

Melnikov, S. V. \& Zhemchugova, V. A. 2000. Lower Silurian stratigraphy of the Timan-northern Ural region and eustatic fluctuation. Proc. Estonian Acad. Sci. Geol., 49, 85-103.

Nestor, H. 1987. Explanations to the stratigraphical schemes of the Silurian strata. In Resheniya mezhvedomstvennogo stratigraficheskogo soveshchaniya po ordoviku i siluru VostochnoEvropejskoj platformy 1984 g. s regional'nymi stratigraficheskimi skhemami (Kaljo, D. L., ed.), pp. 58-112. Izd. VSEGEI, Leningrad (in Russian).

Wenzel, B. \& Joachimski, M. M. 1996. Carbon and oxygen isotopic composition of Silurian brachiopods (Gotland/Sweden): palaeoceanographic implications. Palaeogeogr. Palaeoclimatol. Palaeoecol., 122, 143-166.

\title{
LLANDOVERY JA WENLOCKI PIIR VENEMAA ARKTILISTES PIIRKONDADES
}

\author{
Peep MÄNNIK, Anna ANTOŠKINA ja Tatjana BEZNOSSOVA
}

Llandovery ja Wenlocki piiri asend Timaani-Uurali põhjaosa regiooni ja Severnaja Zemlja läbilõigetes on pikka aega olnud problemaatiline. Erinevatele faunagruppidele tuginevad piiri asendi määrangud ei lange kokku. Konodontide leviku andmed osutavad, et mõlemas regioonis asub Llandovery ja Wenlocki piir läbilõikes oluliselt kõrgemal kui seni arvatud. Konodontidel põhinevad kihtide vanuse määrangud langevad hästi kokku eustaatiliste kõverate põhjal saadud korrelatsioonidega.

\section{ГРАНИЦА ЛЛАНДОВЕРИИ И ВЕНЛОКА В АРКТИЧЕСКИХ РЕГИОНАХ РОССИИ}

\section{Пээп МЯННИК, Анна И. АНТОШКИНА и Татьяна М. БЕЗНОСОВА}

Разделяющая лландовери и венлок граница в разрезах Тимано-Североуральского региона и на Северной Земле до сих пор остается предметом дискуссий. Определение границы по разным группам фауны не совпадает. Так, судя по распространению конодонтов, эта граница проходит в разрезах Тимано-Североуральского региона и на Северной Земле гораздо выше, чем предполагалось до сих пор. Определения возраста отложений по конодонтам хорошо совпадают с корреляциями по кривым эвстатики. 